\title{
Tecendo retalhos contemporâneos: o legado de cangaceiros e fanáticos
}

\author{
Weaving Contemporary Patches: The legacy of cangaceiros and fanatics
}

\author{
Preciliana Barreto de Morais $1^{1 *}$, José Batista de Lima $2^{2}$, Helza Ricarte Lanz $3^{3}$, Rosendo \\ Freitas de Amorim $4^{4}$, Pedro Victor Moura Lima $5^{1}$, Antônio Fábio Macedo de Sousa $6^{5}$, Bruna \\ Maria Costa Gomes $7^{1}$, Luany de Queiroz Silva $8^{1}$
}

\begin{abstract}
RESUMO
Os fenômenos do cangaço e do messianismo têm estimulado uma grande quantidade de elaborações intelectuais e interpretações. Nesse panorama de produções é possível verificar algumas tendências que se configuram a partir de obras paradigmáticas. Tal é o caso do livro Cangaceiros e Fanáticos, do jornalista e escritor cearense Rui Facó, que contribuiu decisivamente para a projeção de um padrão de análise acerca dos fenômenos em questão. O presente artigo busca analisar como Rui Facó aborda os movimentos populares apresentados em Cangaceiros e Fanáticos, inserindo o autor e sua obra no panorama mais amplo dos intérpretes do cangaço e da religiosidade popular, tendo em vista as contribuições e os limites de seu pensamento. Nesse contexto, a pesquisa bibliográfica ora empregada buscou evidenciar as interlocuções do autor com outras produções e tendências interpretativas. Em Cangaceiros e fanáticos, Rui Facó desenvolve um intenso diálogo com a perspectiva de análise consagrada por Euclides da Cunha, com a qual compartilha o tom de denúncia e o desapreço às manifestações da religiosidade popular sertaneja. Estas, tais como as investidas dos bandos de cangaceiros, comporiam o quadro de atraso e ignorância característico dos sertões nordestinos do final do século XIX e início do XX. Contudo, a interpretação de Facó, diferentemente do discurso euclidiano, não incorre em determinismos raciais e ambientais para compreender a sociedade sertaneja. O enfoque analítico de Cangaceiros e fanáticos concentra-se nas dinâmicas socioeconômicas que vigoravam na região Nordeste, com especial destaque para a estrutura fundiária, questão basilar na abordagem de Facó.
\end{abstract}

Palavras-chave: Nordeste; Cangaço; Religiosidade popular; Rui Facó.

\section{ABSTRACT}

The cangaço and messianism's phenomena have stimulated a great deal of intellectual elaboration and interpretation. In this productions panorama, it is possible to verify some trends that are configured from paradigmatic studies. Such is the case of the book Cangaceiros e Fanáticos, by the journalist and writer from Ceará Rui Facó, which decisively contributed to the pattern projection of analysis about the

\footnotetext{
${ }^{1}$ Universidade Estadual do Ceará, Fortaleza, Ceará. *E-mail: preciliana.morais@uece.br

2 Universidade de Fortaleza, Fortaleza, Ceará.

${ }^{3}$ Universidade da Colônia, Alemanha.

${ }^{4}$ Secretaria de Educação do Ceará.

${ }^{5}$ Universidade Federal do Ceará, Fortaleza, Ceará.
} 
phenomena in question. This article intends to analyze how Rui Facó approaches the presented popular movements in Cangaceiros e Fanáticos, inserting the author and his work in the interpreters of cangaço and popular religiosity broader panorama, considering the contributions and limits of his thought. In this context, the bibliographical research used here sought to highlight the author's interlocutions with other productions and interpretive trends. In Cangaceiros e fanáticos, Rui Facó develops an intense dialogue with the perspective of analysis consecrated by Euclides da Cunha, whom he shares the denunciation tone and contempt for the manifestations of popular country religiosity. These kinds of actions, like the onslaughts of bands of cangaceiros, would compose the backwardness and ignorance picture characteristic of the northeastern countries from the late nineteenth and early twentieth centuries. However, Facó's interpretation, unlike the Euclidean discourse, does not incur racial and environmental determinism to understand the country society. The analytical focus of Cangaceiros and Fanaticos focuses on the socioeconomic dynamics that prevailed in the Northeast region, with special emphasis on the agrarian structure that is a fundamental issue in Facó's approach.

Keywords: Northeast; Cangaço; Popular religiosity; Rui Facó.

\section{INTRODUÇÃO}

A luta por territórios e a apropriação de capitais são históricas. Enfrentamentos e conflitos globais entrelaçam-se nos cotidianos das sociedades definindo as formas de agir dos atores sociais, seja numa perspectiva abrangente ou local. No Brasil pós-colonial as disputas trazem em seu bojo fortes traços de um legado social rural que se alastra pelo contexto urbano até os nossos dias. Desde que as lutas e rebeliões rurais foram 'descobertas' no século XIX, elas vêm sendo tratadas, trabalhadas, relatadas e discutidas como uma 'aparição' estranha, misteriosa, alheia aos empreendimentos civilizatórios.

Essas 'aparições' têm chamado a atenção de poetas, artistas, literatas, cancioneiros, como também de cientistas sociais, juristas, historiadores e psicanalistas. Fenômenos sociais, tais como o banditismo social, a pistolagem, as milícias, os capangas, a fé, o misticismo, o messianismo persistem nos cenários contemporâneos. Suas origens são bastante remotas e não se limitam, obviamente, a uma fronteira nacional específica. Não obstante, o cenário político, econômico e social brasileiro, entre o último quartel do século XIX e a década de 1930, revelou-se um campo fértil para o surgimento dos fenômenos em questão, sobretudo, na região Nordeste. Essa fração do território nacional tem, até hoje, sua imagem associada a figuras de cangaceiros e beatos que comporiam uma espécie de "sujeitos nativos" em relação à região (ALBUQUERQUE, 2011)

Ora, tanto quanto os fenômenos do banditismo e messianismo, em si, contribuíram para a conformação dessa base discursiva e imagética as inúmeras interpretações e 
apropriações das figuras de cangaceiros e beatos, em produções artísticas e acadêmicas. Entre estas, a obra Cangaceiros e Fanáticos, de Rui Facó, destaca-se como paradigmática de uma interpretação marxista do cangaço e do messianismo sertanejo. Segundo Bartelt (2009), esse padrão de abordagem resultou em uma radical mudança na percepção que se tinha acerca desses fenômenos, "a demonização deu lugar à heroicização e à sacralização" (BARTELT, 2009, p. 18).

Não obstante a mudança de paradigma que representa, Cangaceiros e Fanáticos traz muitas influências das abordagens que o precederam. Luís Sérgio Santos (2014), biógrafo de Facó, ressalta, por exemplo, a influência de Euclides da Cunha e Graciliano Ramos em Cangaceiros e Fanáticos. O escritor de Os Sertões é uma das fontes a quem Facó mais recorre, o que torna bastante perceptível algumas afinidades de temas e interpretações entre os dois autores, mormente no que se refere à tese do atraso sertanejo como causa do banditismo e do messianismo.

Rui Facó, falecido no início da década de 1960, vítima de um acidente aéreo, era esmerado arquivista e conhecedor profundo desse assunto. Jornalista comprometido em ultrapassar os limites aparentes dos fatos, se propunha a elaborar uma compreensão crítica e contundente dos sujeitos sociais que compunham as veredas de sobrevivência nordestinas. Cangaceiros e Fanáticos, lançado postumamente pela Editora Civilização Brasileira, é uma obra de denúncia, resultado de longos estudos sobre os fenômenos sociais crônicos que têm caracterizado a história do Nordeste.

Inicialmente Facó traça um perfil socioeconômico dos sertões nordestinos, enfatizando as condições que ensejaram os movimentos populares referenciados no título da obra. As mudanças políticas e econômicas que ao final do século XIX despontavam no Brasil pareciam não repercutir no Nordeste, sobretudo na situação das populações rurais da região que continuavam a padecer da exploração e da paralisia social mantidas pelo latifúndio, como vinha ocorrendo desde o período da colonização. O autor destaca o fluxo migratório em virtude da extração da borracha no Norte do país como uma perspectiva de ruptura das populações sertanejas. Outra possibilidade seria o ingresso no cangaço ou nas comunidades lideradas pelos beatos sertanejos, movimentos contestatórios da ordem dominante.

Rui Facó, nas suas análises, deu grande ênfase ao movimento comandado por Antônio Conselheiro. Aí aparece Canudos pintado com cores reais. A origem de seus defensores, o latifúndio improdutivo, a miséria, a ignorância, a exploração do homem 
pelo homem, a religiosidade sertaneja. Nesse abrangente panorama, os grandes fazendeiros figuram como os principais interessados no esmagamento dos "revoltosos" e na perigosa influência que transmitiam aos demais explorados no campo.

O arraial do Belo Monte, que entrou para a história como Canudos, notabilizouse pelos confrontos com as tropas federais, em uma guerra que se projetou em manchetes de jornais e obras literárias. Entretanto, para além dos fuzis e balas de artilharia, a comunidade liderada por Antônio Vicente Mendes Maciel, o Antônio Conselheiro logrou firmar, em pleno semiárido nordestino, uma alternativa de vida para as massas sertanejas submetidas ao jugo dos grandes proprietários.

Com relação ao Contestado no sul do país o autor não entra em detalhes, mas denuncia a classe dominante oprimindo o lavrador que quer a terra também para si. Na declarada demanda por terras dos camponeses do Contestado, Facó vislumbra uma particularidade da mobilização camponesa sulista, "aquela onde a terra foi objeto consciente do conflito armado" (FACÓ, p.38). Ainda que Facó deixe claro que a questão da terra está presente também nos outros movimentos abordados será no Contestado que essa demanda surgirá de maneira mais explícita, de forma mais consciente. Uma consciência adquirida no decorrer das lutas que resultou na eliminação das chamadas “vilas santas” pelo Exército (cf. MENEZES, 2015).

Facó dedica a terceira e última parte de seu livro à análise do Juazeiro de Padim Cícero na qual ressalta a ambiguidade de um movimento cujo potencial revolucionário fora tolhido pelos interesses políticos e econômicos do afamado Padre e de seu mentor para assuntos mundanos, o médico Floro Bartolomeu. Estes, segundo o autor, valendo-se da religiosidade das levas de sertanejos que demandavam o Juazeiro, garantiam a submissão das populações sertanejas aos grandes proprietários rurais, em vista do provimento para os potentados locais de mão de obra barata, constituída dos pobres que afluíam para o Juazeiro. Desse modo, o Padre Cícero não diferia dos impetuosos coronéis do Cariri, diante dos quais o sacerdote juazeirense, inclusive, tinha uma grande ascendência.

Juazeiro do Norte está intimamente ligada à figura de Pe. Cícero Romão Batista, seu grande fundador. O sacerdote, que viveu de 1844 a 1934, teve uma relevante influência naquela cidade, onde exerceu as identidades de líder político, juiz, homem sagrado e médico, respaldado pela autoridade carismática. Chegou inclusive a patentear como capitão um dos grandes cangaceiros da década de 1930, Virgulino Ferreira da Silva, 
o Lampião, com o propósito de que o mesmo aniquilasse a Coluna Prestes. Ainda hoje, Pe. Cícero goza de uma enorme popularidade, sendo considerado o grande santo para a Região Nordeste.

\begin{abstract}
Para Juazeiro ocorrem anualmente milhares de romeiros em busca de lenitivo. Muitos vão pagar promessas por graças alcançadas. Nessas promessas destacam-se os aspectos médicos e as curas. No alto do Horto, local mais elevado da cidade, foi erguida uma grande estátua em homenagem a Pe. Cícero. Com orgulho, os romeiros dizem que é a terceira maior estátua do mundo, olhando o sertão. Sertão de gente simples que fez de Cicero, o Padim, um santo (CAVALCANTE, 2002, p. 280).
\end{abstract}

Desse entrelaçamento de terras e práticas religiosas e culturais surgiu o Caldeirão, uma cria de Juazeiro com feições semelhantes às de Canudos. Os dramáticos eventos que marcaram a destruição da comunidade liderada pelo Beato Zé Lourenço são narrados por Facó, que enfatiza a violência e o autoritarismo das forças de segurança pública, na repressão à comunidade que, contrariando os propósitos dos grandes proprietários de terra da região, vinha atraindo trabalhadores de todo o Nordeste.

O Caldeirão do Beato Zé Lourenço, assim como os outros movimentos populares abordados em Cangaceiros e fanáticos, sucumbira, vitimado por uma repressão que se notabilizou pelo desmedido uso da força (até mesmo aviões foram utilizados contra a comunidade). O movimento é apontado por Facó como o "último exemplo" de "núcleo de cooperados para a lavra da terra e a criação de gado [...] com caraterísticas de misticismo"(FACÓ, 1976,p.208). O escritor cearense, todavia, não aponta o fim desse ciclo de eventos como o resultado de um mero acaso. Pelo contrário, uma caraterística marcante do livro de Rui Facó é a inserção dos fenômenos sociais do cangaço e da religiosidade popular no panorama mais abrangente das transformações socioeconômicas da sociedade brasileira. Nesse contexto, o encerramento do ciclo de rebeliões sertanejas decorre, nas interpretações de Facó, dos processos de modernização e de urbanização que se intensificam na região Nordeste a partir do final da década de 1930.

Uma análise da abordagem que Facó realiza em Cangaceiros e Fanáticos fornece uma perspectiva de como fenômenos sociais como o banditismo e a religiosidade popular têm sido abordados, tendo-se em vista a grande relevância da obra. Inserida no conjunto de interpretações desses movimentos, o livro de Rui Facó sinaliza avanços e limitações que permitiram o advento de novas pesquisas. A compreensão do lugar de Facó nesse cenário, a partir da pesquisa bibliográfica voltada aos fenômenos ora abordados, permite 
apreender diferentes aspectos dos mesmos, tendo uma concepção mais ampla do lugar do cangaço e dos movimentos religiosos populares na sociedade nordestina.

Desse modo, a pesquisa fundamenta-se em uma compreensão socioantropológica e analítica das categorias de cangaço e fanatismo, que figuram na obra de Rui Facó como movimentos socioculturais emblemáticos de um tipo de resistência política no contexto da estrutura de relações sociais que foram forjadas no nordeste brasileiro. A análise do cenário de lutas políticas no qual Cangaceiros e Fanáticos foi produzida ajuda a compreender o padrão de resistência que o autor atribuía aos sertanejos. Facó desenvolveu uma interpretação do banditismo e do messianismo que abordava questões bastante presentes no panorama de demandas sociais do seu período. Destaca-se, nesse contexto, a questão dos danos causados pela concentração fundiária como um fator constante na organização socioeconômica brasileira a promover a revolta das populações campesinas.

O presente artigo fará, em sua primeira parte, uma apresentação geral do pensamento de Rui Facó, ressaltando alguns aspectos importantes de sua atividade intelectual. Nessa perspectiva, destaca-se o engajamento político do autor que reverbera intensamente em sua produção. Nesse primeiro tópico, será discutido também os aspectos gerais da interpretação de Facó dos movimentos sociais camponeses. A segunda e a terceira parte serão dedicadas, respectivamente, ao cangaço e às comunidades religiosas sertanejas, enfatizando os aspectos da interpretação de Facó acerca dos mesmos. A última parte trará uma reflexão sobre algumas aproximações e distanciamentos entre os fenômenos abordados em Cangaceiros e Fanáticos.

\section{RUI FACÓ E SUAS ELABORAÇÕES ANALÍTICAS}

A obra de Rui Facó evidencia o dinamismo de um autor engajado com as transformações na sociedade brasileira. Nesse sentido, em Cangaceiros e Fanáticos, o escritor cearense traça um panorama dos movimentos populares sertanejos da segunda metade do século XIX e início do século XX, a partir de uma problemática central: a questão da terra. É a estrutura social patriarcal, autoritária e excludente, engendrada pelo latifúndio, que serve de esteio para as revoltas camponesas abordada no célebre livro de Facó.

Otto Maria Carpeaux (apud Santos, 2014, p.67 em um artigo que aborda Canudos, à luz de Euclides da Cunha e Rui Facó, conclui que "cada geração, das que se sucedem, 
encontra algo de novo naquela história impressionante[Canudos]". Rui Facó, como bem evidencia o texto de Carpeaux, é um desses intérpretes inovadores de Canudos, trazendo, para a interpretação daquele evento, algo não apenas novo, mas atual. Urgente, pode-se falar.

Acerca dessa atualidade, cabe mencionar que Facó não cai na armadilha de transplantar, de maneira automática para o período dos eventos analisados questões referentes ao tempo em que elabora a obra, a década de 1950. Em Cangaceiros e Fanáticos, o autor contextualiza o problema da terra no panorama mais abrangente do conjunto de transformações sociais operadas no Brasil no início do século XX. Nessa perspectiva, o autor não apenas ressalta que a ebulição popular nordestina, de que trata em seu livro, é o resultado de transformações que atingiram as populações sertanejas, como a abolição da escravidão e as correntes migratórias para a região amazônica, como deixa claro que a situação das populações rurais do Nordeste se tinham modificado bastante desde a década de 1930, período em que se encerra o ciclo de rebeliões populares abordado em Cangaceiros e Fanáticos.

Possivelmente, essas transformações subsequentes aos fenômenos de Cangaceiros e Fanáticos serviriam de mote para outras produções de um intelectual inquieto que encontrou a morte, em 1963, em um acidente aéreo nos Andes, quando viajava pela América Latina colhendo material "para uma série de extensas reportagens sobre problemas sociais e políticos do cone sul” (SANTOS, 2014, p.25). Facó faleceu pouco tempo antes da publicação de Cangaceiros e Fanáticos. O livro já estava concluído, mas a intensa atividade intelectual de Facó persistia, bem como a sua ânsia por transformações sociais, mormente no que se refere à questão fundiária.

Militante ativo do Partido Comunista Brasileiro, destacando-se entre os intelectuais do Partido, Facó interpretava a realidade a partir de uma perspectiva marxistaleninista, tendo em vista as especificidades da sociedade brasileira e as condições para a sua transformação. A linguagem empregada por Facó em sua obra já sugere o compromisso do autor com uma pronta mudança da sociedade.

Cangaceiros e Fanáticos, a partir de uma análise do panorama de forças das classes sociais no Brasil, descreve as transformações da sociedade brasileira e o reflexo destas nos sertões nordestinos. Os levantes sertanejos que proliferaram pelo Nordeste entre o final do século XIX e a década de 1930 compõem na obra de Facó episódios da “Guerra Civil Nordestina” (FACÓ, 1976, p. 180). No cenário descrito por Facó, tal guerra 
deriva de um momento de declínio das oligarquias rurais que restam minadas por movimentos de modernização da sociedade brasileira.

As rebeliões camponesas abordadas por Facó seriam resultantes dessa estrutura apodrecida que já não podia conter os ímpetos revolucionários das massas camponesas, submetidas ao latifúndio "semifeudal", como o denominou Facó. Diante do quadro de intensa exploração, agravado pela severidade climática da região, a adesão ao cangaço não representava apenas uma possibilidade de sobrevivência. Juntar-se a um grupo de cangaceiros era voltar-se, em franca revolta, contra a ordem latifundiária. Ainda que orientada por fatores inconscientes, sem qualquer organização programática, as ações dos cangaceiros representavam um passo inicial na luta contra a ordem constituída.

Era contra essa mesma ordem que lutavam as comunidades religiosas. Nesses agrupamentos, percebe-se, segundo Facó, um embrião da luta pela terra. Esta seria a questão central desses movimentos, estando a motivação religiosa apenas na superfície dos eventos. É que, tal como entre os cangaceiros, essa revolta contra a ordem opressora operaria no inconsciente dos "fanáticos", encoberta pelos argumentos religiosos que compunham o cotidiano de populações regionais.

Em Cangaceiros e Fanáticos, o elemento religioso fornece para as populações sertanejas um fulcro ideológico. Ainda assim, cabe ressaltar que Facó não incorre na retórica tão recorrente em interpretações dos movimentos religiosos sertanejos que associam o que entendem como "fanatismo" a questões raciais. Na realidade, o escritor cearense não poupa críticas a tais argumentos. O "mais completo atraso" a que estavam submetidos os sertanejos, o qual concorreria para o advento das comunidades religiosas, seria uma consequência do latifúndio, enfatiza reiteradamente Rui Facó.

Eram muito mais frutos do nosso atraso econômico do que eles próprios retardatários. Hoje, compreendemos e sentimos que eles eram uma componente natural do nosso processo evolutivo, a denúncia do nosso próprio retardamento nacional, o protesto contra uma ordem de coisas ultrapassadas e que deveria desaparecer" (FACÓ, 1976, p. 8).

São, todavia, perceptíveis os aspectos normativos no discurso de Facó, tanto no que se refere à conformação de um "processo evolutivo", determinando o que "deve desaparecer", quanto nos padrões utilizados para determinar o que seria "atrasado" ou "obscurantista". Levando-se em conta o cenário de tensões entre a Igreja e as 
comunidades religiosas dos sertões, não seria difícil supor que os sertanejos tivessem, também, a impressão de um discurso "deturpado" por parte das determinações provenientes de Roma. Facó, contudo, parece alinhar-se automaticamente ao ponto de vista da Igreja.

Em grande medida, esse alinhamento decorre do fato do autor tratar de maneira superficial questões referentes à cosmovisão das populações sertanejas. Com isso, Facó compromete bastante a sua compreensão acerca, inclusive, de aspectos importantes da organização sociopolítica e econômica das comunidades, na medida em que exclui do campo de análise os significados que os indivíduos atribuem às suas ações, as quais figuram, na interpretação do autor, na vala comum do "obscurantismo". Tal postura diante do que seria o "fanatismo", constitui uma forte tendência entre os intérpretes de movimentos como Canudos, Juazeiro e Contestado, e decorre de:

Uma atitude metodológica presente numa tradição racionalista, na qual religião é equacionada como ignorância e, ato seguinte, é tomada como mero epifenômeno a ser desconsiderado, sendo tomada como uma capa que esconde o que seria o essencial (MENEZES, 2015, p. 141).

Não obstante, onde Facó vislumbrou "ensinamentos bíblicos deturpados", é possível destacar uma apropriação bastante criativa dos dogmas católicos. Vasconcellos, que organizou uma publicação dos cadernos de prédicas do Conselheiro, destaca como o líder de Canudos elabora uma interpretação da doutrina católica não apenas consoante ao contexto vivido pelo arraial, mas também mutável, atendendo às exigências das circunstâncias. "É justamente o Belo Monte que proporciona ao Conselheiro a possibilidade de reelaborar dados básicos, constitutivos do universo religioso que deu norte a sua existência" (VASCONCELLOS, 2017, p. 198).

Facó não teve acesso às prédicas do Conselheiro publicadas pela primeira vez em 1974 por Ataliba Nogueira. Ainda assim, o escritor cearense procura esmiuçar o contexto social no qual se desenvolve o que se convencionou denominar de "fanatismo". Desprezando os tão recorrentes argumentos deterministas envolvendo aspectos raciais e climáticos, o autor de Cangaceiros e Fanáticos denuncia as condições materiais que ensejaram o advento dos movimentos populares sertanejos do final do século XIX e início do século. Ao promover uma reflexão sobre o protagonismo das populações sertanejas em tais movimentos, a obra de Facó torna-se um marco, influenciando muitos trabalhos 
que a sucederam. Muitas dessas pesquisas, dispondo de mais fontes e de outras perspectivas de análise, resultaram em mergulhos mais profundos no universo de sentidos desses movimentos, revelando as nuances do que Facó compreendeu como "deturpado" ou "obscurantista".

\section{O CANGAÇO}

Em Cangaceiros e Fanáticos, Rui Facó procura perscrutar os fatores socioeconômicos que ensejaram o advento dos movimentos camponeses do Nordeste brasileiro do final do século XIX e início do século XX. Tratava-se de uma abordagem até então incomum para um tema bastante abordado, como reconhece o próprio Facó, assinalando também o cerne do problema, segundo a sua interpretação:

Relatos existem, numerosos. Interpretação, nenhuma. Quando muito, este ou aquele autor se anima a emitir uma consideração a vôo de pássaro sobre as origens do cangaceiro ou do fanático. A própria aceitação da ordem de coisas vigente e a crença na sua imutabilidade determinavam os preconceitos e os erros para compreender os fenômenos patológicos resultantes (FACÓ, 1976, p. 3).

A "aceitação da ordem de coisas vigente", este seria o grande empecilho para a compreensão de fenômenos que indicam transformações. Nesse sentido, não apenas o cangaço seria um produto da ordem "semifeudal" vigente nos sertões, como a maior proliferação de cangaceiros, que se observa do último quartel do século XIX até a década de 1930, seria indício de uma sociedade em transformação, contrariando a perspectiva que apresentava os sertanejos como "retardatários".

$\mathrm{Na}$ interpretação de Facó, mais do que indícios de transformações, os grupos de cangaceiros espalhados pelos sertões expressavam o clamor por mudanças, um protesto mal direcionado de uma população que já não suportava mais a exploração, mormente no que se refere à concentração de terras. $\mathrm{O}$ cangaceiro é assim um rebento do latifúndio, e não apenas no que se refere à revolta que essa ordem provoca nesses sertanejos, instandoos à rebeldia, mas também em virtude da estrutura de violência sobre a qual se sustenta a grande propriedade rural sertaneja. Tal violência pode ser sintetizada na figura do capanga e do jagunço, espécie de êmulo do cangaceiro, a serviço do fazendeiro. 
Facó destaca como os proprietários rurais se valiam desses capangas para a manutenção de seus domínios. Os inúmeros relatos de conflitos envolvendo os potentados locais evidenciam verdadeiros exércitos desses trabalhadores que trocavam as enxadas pelas espingardas a mando do fazendeiro. Por vezes, alguns desses capangas abandonavam o jugo do proprietário rural e se lançavam no cangaço, atuando não apenas de maneira independente, mas também contrária ao fazendeiro. Voltavam-se assim, segundo Facó, contra a própria ordem socioeconômica que os explorava e os privava da terra.

De acordo com Facó, contudo, os cangaceiros não tinham consciência de suas motivações sociais de classe. Suas ações careciam de organização ou de conteúdo previamente definidos. "Não era ainda uma luta diretamente pela terra, mas era uma luta em função da terra" (FACÓ, 1976, p. 37). Quanto a essa falta de "politização", o autor aproxima cangaceiros e comunidades religiosas tidas como "fanáticas". Ambos não teriam a real consciência do que os impelia à luta. Contudo, entre essas duas formas de rebelião, que o autor compreendia como "primitivas", o cangaço seria uma revolta ainda anterior. "O cangaço precede os grandes ajuntamentos de "fanáticos" que tiveram seus pontos culminantes em Canudos e no Contestado" (FACÓ, 1976, p. 38).

Para Facó, os agrupamentos religiosos em conflito com o Estado podiam até adquirir, no decorrer da luta, alguma consciência de suas reais motivações, como, segundo o autor, já vinha acontecendo com os camponeses do Contestado. Com os cangaceiros, o autor não aponta os mesmos indícios de conscientização. Contudo, na interpretação de Facó, o cangaço parece ter a maleabilidade indicada por Hobsbawm (2017) que aponta como os "bandidos" podiam se encaixar em grupos revolucionários ou milenaristas, dada a sensibilidade que tinham em relação às questões levantadas por tais grupos, afinal compartilhavam das mesmas origens sociais. "Quando o banditismo se funde com um movimento de maiores proporções, torna-se parte de uma força capaz de mudar a sociedade, e que efetivamente a muda" (HOBSBAWM, 2017, p. 49).

Nesse sentido, Facó não apenas cita a participação de cangaceiros em Canudos, como é bastante incisivo em suas críticas ao Padre Cícero, que através de uma atuação que conciliava as massas camponesas às elites rurais, provocava o "desbaratamento de forças potencialmente revolucionárias". Assim, a comparação que Facó faz entre Antônio Conselheiro e Padre Cícero, aclamando o primeiro e criticando o segundo, leva em conta, justamente, a condução da luta armada e a insubordinação: “...Antônio Conselheiro reagia 
a mão armada, enquanto o Padre Cícero pregava a obediência e a humildade" (FACÓ, 1976, p. 170).

Na obra de Facó, a relação do Padre Cícero com o cangaço enseja a reflexão dos vínculos entre cangaceiros e movimentos religiosos, bem como entre o cangaço e os grandes proprietários rurais, uma vez que o padre de Juazeiro tanto era tido como um santo junto às populações pobres, como figurava entre os mais destacados líderes políticos do Nordeste. A tentativa do Padre Cícero de cooptar o grupo de Lampião para combater a Coluna Prestes, em 1926, indica a proximidade entre os cangaceiros e os potentados locais. O recrutamento daquele que já era o mais célebre cangaceiro dos sertões deu-se com a total anuência das elites rurais e dos Poderes Públicos que se viam ameaçados por Prestes. Facó sustenta a hipótese em relação a esse evento, que ao final, prevalece a identificação do grupo de Lampião com os pobres camponeses sertanejos, que não viam nenhuma ameaça em Luiz Carlos Prestes e seus comandados. Dessa forma, se justificaria a desistência do grupo de Lampião de perseguir a Coluna Prestes.

Ainda assim, Facó não deixa de pontuar que a relação entre cangaceiros e grandes fazendeiros não se limitava a um simples antagonismo. O cangaço, reconhece o autor cearense, se valia do latifúndio, tanto para encontrar abrigo no que dependia da figura do "coiteiro", quanto para a contratação de seus serviços, quando o antigo rebelde se tornava um "cangaceiro manso" a serviço do latifundiário. Hobsbawm também ressalta os vínculos entre cangaceiros e fazendeiros, destacando que os bandidos conseguiam "auferir vantagens" do cenário de disputas entre os grandes proprietários de terra. Segundo o historiador britânico, o proveito desse tipo de situação possibilitava que alguns bandos fossem bastante longevos: "É por esse motivo que em áreas distantes da autoridade central, como o Nordeste brasileiro até 1940, bandos famosos conseguiam sobreviver por períodos surpreendentemente longos" (HOBSBAWM, 2017, p. 120).

Cabe pontuar, nessa questão, uma sútil diferença nas abordagens de Facó e Hobsbawm, mas que evidencia um aspecto importante de Cangaceiros e Fanáticos. Enquanto o historiador britânico menciona cangaceiros auferindo "vantagens" do turbulento cenário político da região, Rui Facó fala mais da ação corruptora dos latifundiários, em relação aos cangaceiros, e de "bandos autônomos" "enredados nas malhas do latifundiário". Em suma, o escritor cearense evidencia, de uma forma mais enfática, o cangaceiro como uma vítima da ordem social que o origina. 
A ênfase acima referida decorre do fato de Cangaceiros e Fanáticos ser uma grande denúncia dos males produzidos pelo latifúndio. Nesse sentido, o autor destaca todo o atraso de uma região que permanecia isolada e refém de uma ordem estrutural, encabeçada pelo latifundiário, a submeter a população a um estado de exploração e apatia. O cangaço seria, assim, uma "legítima" revolta contra tais condições. Seus meios de ação e objetivos seriam compatíveis com a conjuntura de atraso social da sociedade sertaneja. Não obstante, onde faltava a estratégia ou o discurso, Facó reconhecia o potencial para a luta insurgente. Desse modo, o cangaço era alçado à condição de exemplo do caráter insubmisso do campesinato brasileiro, a animar os novos rumos da luta pela terra no Brasil, os quais Rui Facó não perdeu de vista na elaboração de seu livro.

Ao final da década de 1930, o cangaço decai. Sua queda vem acompanhada da decadência política das elites rurais que perdem cada vez mais espaço para a burguesia. O latifúndio, contudo, resiste, sobrevivendo dos compromissos que mantém com a ordem burguesa. Não possui o poder político de outrora, mas permanece com uma significativa força no interior do país, o que não é desprezado pela burguesia. Todavia, também resistem os camponeses, munidos de um maior grau de consciência e capacidade de organização. Assim, mesmo vencida pelas elites, a "Guerra Civil do Nordeste" não encerra os movimentos emancipatórios das populações camponesas, que, à época em que Facó concebeu Cangaceiros e Fanáticos, articulavam-se nas ligas camponesas e em associações de lavradores, como bem destaca o escritor cearense ao final de sua obra.

\section{O "FANATISMO"}

Praticamente dois movimentos de rebelião dos camponeses do Nordeste marcam respectivamente o surgimento e o desaparecimento do que Facó chamou de "Guerra Civil Nordestina". Estes pontos demarcadores são Canudos (1896-1897) e Caldeirão (19361938). Apesar de muitas características comuns dos dois movimentos, liga-os traço comum sobressaltante: o choque entre a religiosidade popular e a religião oficial da Igreja dominante (STUNTEBECK, 2016; RICARTE LANZ, 2018). A compreensão de tal choque perpassa as especificidades da religiosidade sertaneja, bem como mudanças no posicionamento da Igreja em relação à tolerância de manifestações que escapassem ao controle de Roma.

Nos sertões nordestinos, o último quartel do século XIX foi um momento de acentuadas contradições no que se refere às práticas religiosas. O choque entre uma 
população que desenvolvera referenciais religiosos bastante particulares e uma Igreja que procurava centralizar e enrijecer o controle do credo católico é bastante nítido nos movimentos religiosos abordados em Cangaceiros e Fanáticos. Tal embate pode ser percebido, inclusive, dentro do próprio clero católico, como demonstra a adesão inicial de alguns sacerdotes à causa do Padre Cícero (DELLA CAVA, 2014).

Até mesmo o Conselheiro, em suas andanças pelos sertões, contou com a condescendência de alguns padres, que aceitavam as pregações do religioso cearense em suas paróquias, como informa Calasans (1988). Assim, o choque entre o catolicismo popular e a Igreja oficial não ocorre a partir de uma oposição entre dois pólos completamente antagônicos. Há nuances, marcando proximidades e contatos, além de divergências no interior do próprio clero brasileiro, com alguns de seus setores resistindo à centralização do credo a partir de Roma. Vasconcellos (2017), por exemplo, ressalta como entre os conselheiristas não havia uma rejeição aos dogmas católicos, sendo inclusive franqueada a entrada de alguns sacerdotes em Canudos. Apesar disso, o autor destaca que, entre os seguidores do Conselheiro, havia a impressão de degeneração da postura da Igreja:

\begin{abstract}
Aos olhos do Conselheiro e de sua gente, é a Igreja Católica que está mudando: a maior evidência disso é a adesão que muitos de sua hierarquia estão dando ao nefasto regime republicano, bem como a hostilidade manifesta às expressões tradicionais da devoção (VASCONCELLOS, 2017, p. 164).
\end{abstract}

Tal estranhamento não era fortuito, a centralidade que a Igreja católica procurava implantar chocava-se com uma religiosidade que desenvolveu-se às margens das atividades clericais. $\mathrm{O}$ fato é que as dispersas populações sertanejas quase não tinham acesso aos ofícios dos sacerdotes católicos. Segundo Mello (2014), no ano de 1861, a Província do Ceará contava com 33 padres, prestando assistência religiosa a uma população de 720 mil pessoas. Esse levantamento, realizado por iniciativa de Dom Luís Antônio dos Santos, primeiro bispo da Diocese do Ceará, informava, ainda, que mais de dois terços desse reduzido número de sacerdotes tinha "família constituída".

A nova postura de Roma, difundida, no Brasil, a partir dos seminários (DELLA CAVA, 2014), choca-se com esse cenário de "tolerância" e "escassez”, mantido pela Igreja Católica no Brasil, que atuava como uma instituição do Império, sendo os padres considerados funcionários públicos. A chamada Questão Religiosa de 1872 marca, a 
partir da prisão de jovens bispos não alinhados aos ditames imperiais, uma grave crise entre o Trono e a Igreja, que se estendeu durante os anos finais do Império.

Nos sertões Nordestinos, a reação à escassa e indecorosa classe sacerdotal veio a partir da ação apostolar de alguns missionários, cujo exemplo mais notável é, certamente, o do Padre José Maria Ibiapina. Munido de uma pregação bastante rígida, o Padre Ibiapina atravessou o interior de vários estados nordestinos, estabelecendo um modelo de atuação pautado no ascetismo, na construção de obras religiosas e na constante itinerância. Curiosamente, Facó cita trechos de uma célebre biografia do Padre Ibiapina, mencionando à Revolta do Quebra Quilos, que está relacionada à trajetória do sacerdote sertanejo, mas sem fazer qualquer referência direta a essa importante figura da religiosidade sertaneja, a quem Della Cava (2014) atribui o "renascimento religioso" do Vale do Cariri.

Para além da veneração em torno da sua figura, o Padre Ibiapina tem um papel de grande destaque na configuração assumida pela religiosidade popular sertaneja a partir da segunda metade do século XIX. Isso, em grande medida, porque o Padre, nascido nos arredores de Sobral - CE, fundou, a despeito da proibição de Roma, uma ordem religiosa, que serviria de inspiração para os inúmeros beatos que cruzavam os sertões nos anos seguintes (POMPA, 2015). É nítida a influência da trajetória e da obra do Padre Ibiapina na formação religiosa de Antônio Conselheiro, quer seja no modelo de vida apostolar itinerante, deixando obras pelos lugares visitados, ou mesmo na adoção de uma carreira religiosa à margem da estrutura clerical católica, para o que influiu a ordem religiosa não reconhecida por Roma, que o Padre Ibiapina instituíra. Nesse sentido, Arruda (2006, p.86) é taxativo quanto à impressão causada pelo Padre Ibiapina em Antônio Conselheiro: “o santo padre itinerante passou a ser o grande paradigma de vida religiosa de Antônio Vicente.

Peregrinar sem um destino certo, orar, praticar jejuns, promover e viver da caridade, estas eram algumas das ações realizadas pelos muitos beatos que varavam os sertões. Alguns desses se destacavam como pregadores, alcançando o status de conselheiro, como ocorreu com Antônio Vicente Mendes Maciel, que entraria para a História como Antônio Conselheiro. O fato é que muitos desses beatos mediavam o contato que a população sertaneja tinha com o catolicismo.

Nesse sentido, os beatos eram figuras limítrofes, por vezes, prestando serviços à igreja, no que contavam, quando não com a simpatia, ao menos com a tolerância de alguns 
membros do clero Católico, mas também reverberando as demandas das populações sertanejas, com quem compartilhavam, de maneira muito próxima, o cotidiano e as diversificadas crenças religiosas. Tal ambiguidade não era bem vista por uma Igreja empenhada com “a imposição de padrões europeus” (DELLA CAVA, 2014, p. 71).

Desse modo, os embates entre uma Igreja "romanizada" e as expressões da religiosidade popular sertanejas tornam-se frequentes, chegando aos atos extremos cometidos em Canudos e no Caldeirão, os quais contaram com a anuência de grande parte do clero Católico. No Juazeiro, essa tensão prolonga-se, sem os terríveis desfechos dos movimentos acima citados, graças, em grande parte, aos compromissos assumidos pelo Padre Cícero com as elites caririenses, a partir da mediação implacável de Floro Bartolomeu.

No Juazeiro, a religiosidade popular opunha-se aos preceitos ditados por Roma, sobretudo, na crença em milagres praticados pelo Padre Cícero. Nesse caso, as disputas entre a norma católica e as crenças sertanejas ocorreram bem longe dos sertões nordestinos. É em Roma, na sede da Igreja Católica, onde o Padre de Juazeiro vai procurar se defender das acusações de "ter alardeado, ou permitido que alardeassem em seu nome, supostos milagres" (FACÓ, p. 135). Segundo Facó, tais imputações, “todos o sabiam”, tinham sido a causa para a suspensão de ordens do padre.

Facó faz severas críticas ao Padre Cícero, a quem acusa de explorar a crença das populações sertanejas, em favor da manutenção da ordem "semifeudal". O escritor cearense chega a incorporar, em suas críticas ao padre, os mesmos elementos das acusações de Roma contra o sacerdote cearense, ao alegar que o Padre Cícero era condescendente com a crença herética em seus milagres:

Porque o sacerdote nem uma só vez desautorizou os consabidos embustes apresentados como milagres seus, preferindo, pelo silêncio, alimentar a crença de que era capaz de fazê-los (FACÓ, 1976, p. 62).

É bastante contraditório o alinhamento do discurso de Facó com as acusações da Igreja, uma vez que o escritor exalta, ao longo de sua obra, o caráter insubmisso da religiosidade sertaneja. Fica patente, nesse caso, além da crítica ao Padre Cícero, a compreensão que o autor tinha dos aspectos propriamente devocionais das comunidades religiosas, tendo-as, nesse aspecto, como "fanáticas".

Facó compara a posição do Padre Cícero com a de Antônio Conselheiro. Este, em virtude de seu enfretamento à ordem dominante, é louvado pelo escritor, que, para tanto, 
contraditoriamente, se vale dos padrões de julgamento da Igreja, os quais, conforme mencionado, comprometiam o Padre de Juazeiro. Sobre Antônio Conselheiro, Facó (1976, p. 85) ressalta: "Entretanto, não há um só testemunho de que o Conselheiro se arvorasse em fazedor de milagres". Enquanto a falta de "um só testemunho", no caso de Antônio Conselheiro, contenta o autor, o silêncio do Padre Cícero em relação aos milagres a ele atribuídos é visto como negativo. Contudo, o que mais chama a atenção nesse caso é a acolhida, por parte de Facó, de um discurso proveniente do dogmatismo católico, acionado com os mesmos objetivos da Igreja: para condenar ou absolver.

\section{APROXIMAÇÕES E DISTANCIAMENTOS ENTRE CANGACEIROS E FANÁTICOS}

Rui Facó aponta que Euclides da Cunha, em Os Sertões, não faz distinção entre cangaceiros e fanáticos, "talvez" porque a campanha de Canudos "englobasse a todos" indistintamente. Contudo, para além dos variados grupos que se reuniram em Canudos, essa indistinção aponta também um reducionismo, sobretudo, quanto ao caráter da religiosidade sertaneja, que, enquadrada como um fenômeno semelhante ao cangaço, apresenta o estigma da violência e da irracionalidade. Uma religiosidade descrita como patológica e que, portanto, deveria ser sanada. O fanático entra, assim, tal qual o cangaceiro, no rol dos inimigos do progresso. A descrição que Euclides da Cunha faz da cerimônia "do beijar das imagens" elucida a imagem do "fanático" arquitetada pelo célebre autor fluminense: "Apertando ao peito as imagens babujadas, mulheres alucinadas tombavam escabujando nas contorções violentas da histeria" (CUNHA, 2017, p. 210).

O próprio Facó aponta como essa generalização opera, tendo em vista o uso do termo "jagunço" para designar todo e qualquer seguidor de um dos grandes líderes religiosos dos sertões, "os jagunços do Conselheiro", "jagunços do Padre Cícero” (FACÓ, 1976, p. 52). Calasans (2000, p.89) aponta como até mesmo as crianças de Canudos eram designadas por esse termo, que, como bem aponta Facó (cf. p. 52), é um sinônimo de capanga. "Jaguncinho é o menino-jagunço, quase sempre sem pai nem mãe, que os soldados iam encontrando" (CALASANS, 2000, p.89).

Facó aproxima cangaceiros e fanáticos como elementos em choque com as elites

rurais. Não obstante essa aproximação, o autor pontua o papel da terra como elemento 
distintivo das comunidades religiosas. A apropriação de um pedaço de terra, para Facó, seria uma marca de movimentos como Canudos e Caldeirão. Estes, bem como o Contestado, no sul do país, foram movimentos de massas, o que também os diferenciaria, segundo Facó, do cangaço, que não teria o mesmo potencial para atrair as "massas pobres do campo" (FACÓ, 1976, p. 62).

É, de fato, notória a capacidade atrativa, junto à população sertaneja, dos movimentos acima mencionados. Contudo, é preciso pontuar que, embora não tenha sido um movimento de massas, o cangaço empolgava a juventude sertaneja (JASMIN, 2016), sobretudo, no momento em que passa a figurar, a partir de registros visuais e materiais de imprensa, como um modo de vida ostentatório, distinguindo-se, dessa maneira, dos antigos grupos de cangaceiros.

Desse modo, percebe-se não ser possível apontar uma uniformidade nem mesmo dentro do fenômeno cangaço, havendo sensíveis diferenças entre os grupos liderados por Lampião e aqueles que os precederam. Mais difícil ainda seria estabelecer essa uniformidade no que se refere à religiosidade sertaneja, que caracteriza-se, justamente, pelas variadas influências que a constituem, manifestando, além dos componentes cristãos, diversos aspectos das crenças indígenas e africanas. Segundo Arruda (2006), a característica "sui generis" da formação socioreligiosa sertaneja seria "a excessiva predisposição positiva para aceitar os mais variados apelos religiosos" (ARRUDA, 2006, p. 63).

Nesse sentido, há uma grande variabilidade no que Pompa (2015) denominou de "rituais e agentes do catolicismo rural", os quais são constantemente ressignificados, como também apontou a autora, que analisou como algumas "manifestações da devoção popular" passaram por um processo de ressignificação entre os participantes da comunidade de Pau de Colher, movimento religioso criado por remanescentes do Caldeirão do Beato Zé Lourenço.

As própria ações do Padre Ibiapina revelam essa dinâmica de constantes ressignificações dos elementos da religiosidade popular. O padre cearense, cuja atuação apostolar calcou-se, em grande medida, em práticas devocionais presentes no cotidiano das populações sertanejas, estabeleceu as bases, na região do Cariri, para a criação de “ordens religiosas genuinamente brasileiras" (DELLA CAVA, 2014, p.69). Assim, as manifestações religiosas sertanejas, que Euclides da Cunha compreendeu como ecos da Idade Média, e que Facó interpretou como "deturpações", são, na verdade, mais 
dinâmicas do que sugerem os olhares que as medem pelos parâmetros do progresso e da "modernidade" da nação.

Dinâmicas, também, eram as ações dos cangaceiros, o que gerava grande incômodo entre os defensores da modernidade: "Lampião incomoda também porque ele utiliza os artifícios e os instrumentos dessa 'modernidade', desse mundo moderno que, no entanto, se sente tão diferente dele" (JASMIN, 2016, p. 193). Em sua feroz crítica ao estado de atraso predominante na ordem "semifeudal" sertaneja, Facó perde de vista muitas dessas nuances do banditismo sertanejo, as quais revelam as porosidades entre a "modernidade" e a ordem "semifeudal".

Pesquisas recentes têm se aprofundado em aspectos como a presença feminina no cangaço (NEGREIROS, 2018), a estética cultivada pelos cangaceiros (MELLO, 2015) as tensões narrativas em torno de figuras como Lampião (JASMIN, 2016). No que se refere aos movimentos religiosos, há trabalhos que abordam temas como a conjuntura política que envolvia Canudos (SAMPAIO, 2001), a formação de discursos em torno daquele arraial (BARTELTt, 2009), o imaginário social no Contestado (MENEZES, 2015), as memórias do movimento de Pau de Colher (POMPA, 2015) e muitos outros. Essas pesquisas, pela diversidade de temas que abordam, revelam a complexidade de fenômenos como o cangaço e as comunidades religiosas sertanejas, os quais têm sido abordados como expressões bastante distintas entre si, demandando pesquisas específicas. .

Entretanto, na cultura popular ainda é bastante comum cangaceiros e fanáticos figurarem juntos, tal como no livro de Rui Facó. Na produção cinematográfica, filmes do chamado "cinema novo" apresentam beatos e cangaceiros como símbolos de insurgência e rebeldia. É notória a influência da obra de Facó na configuração desses símbolos em torno de tais fenômenos. Uma configuração simbólica que ultrapassa os limites do sertão, alcançando a intelectualidade urbana. Bartelt (2009, p. 18) ressalta como esse padrão de abordagem operou sobre a figura de Antônio Conselheiro, vigorando até o momento atual: "O Conselheiro foi - e ainda continua a ser - considerado uma figura 'sacrossanta', não só pelos movimentos sociais contemporâneos, mas também por muitos intelectuais do litoral".

\section{CONSIDERAÇÕES FINAIS}


As interpretações recorrentes sobre o cenário brasileiro nas obras clássicas sobre o cangaço e o fanatismo religioso apresentam paradoxos. Tanto o cangaço, quanto a religiosidade popular são vistos, discutidos e apresentados como fenômenos sociais arcaicos, fadados a tornarem-se obsoletos com o desenvolvimento civilizatório. Nolens volens somos filhos do Iluminismo Europeu e acreditamos que há progresso socioeconômico e aperfeiçoamento moral e ético do ser humano. Nessa perspectiva, as revoltas camponesas, o banditismo social e a sua religiosidade são interpretadas como resquícios de um mundo rural arcaico.

A obra de Rui Facó, em sua denúncia direta ao latifúndio, por vezes, recorre a tais argumentos e compartilha dessa crença na modernidade. A obra Cangaceiros e Fanáticos busca inserir os fenômenos do cangaço e do messianismo em um amplo esquema interpretativo da história do Brasil pela dinâmica de lutas de classe a partir da passagem do "primitivismo" para a modernidade, com o consequente desaparecimento dos movimentos em questão.

Nesse sentido, diversos aspectos da religiosidade sertaneja são negligenciados, restando apenas a descrição do fanatismo. Entretanto, tal carência não resulta de um descuido. Facó inicia seu célebre livro criticando as abordagens que atribuem a existência de movimentos como Canudos somente ao fanatismo. Para o escritor cearense, tal fenômeno seria um produto do atraso da ordem semifeudal, erigida a partir do latifúndio. Assim, Facó busca abordar o que entende ser a essência da questão, descuidando-se do que define como a "exteriorização" do fenômeno.

Desse modo, ainda que até mesmo critique o termo fanático, entendido como uma classificação proveniente "de fora, dos meio cultos para o sertão", Facó não rejeita a definição de fanatismo proposta pelos "meios cultos". Na realidade, o autor mantém, ao longo de todo o seu livro, um intenso diálogo com aquele que foi certamente o grande intérprete dos sertões para os "meios cultos", Euclides da Cunha. Mesmo rejeitando, peremptoriamente, as teorias raciais que embasaram as argumentações do escritor fluminense, Rui Facó entendia, como Euclides da Cunha, que a modernidade suplantaria o banditismo e o fanatismo.

No entanto, apesar de toda modernização das formas de produção, do aparato estatal, das instituições estatais, sabemos que há milícias e capangas modernos, praticamente, em todas as cidades e localidades brasileiras. Há focos de lutas e revoltas urbanas que se assemelham estruturalmente às lutas cangaceiras e são, hoje como no 
passado, brutalmente sufocadas pelo Estado. O fanatismo religioso não acabou, mas adequou-se aos novos tempos. A religiosidade, a fé e as práticas religiosas populares têm penetrado o contexto rural e urbano.

Há uma discrepância entre um desejo amplo e legítimo de acabar com a exclusão social e a persistência de fenômenos sociais que existiram no passado e com os quais nós nos deparamos na atualidade. A visão etnocêntrica de uma população tida como atrasada culturalmente não nos ajuda a compreender a realidade brasileira. Atribuir uma sequência temporal de começo, meio e fim é um equívoco, pois esses fenômenos sociais não foram extintos e persistem apesar de mudanças e alterações estruturais até os dias atuais.

\section{REFERÊNCIAS}

ALBUQUERQUE JÚNIOR, Durval Muniz de. A invenção do Nordeste e outras artes. São Paulo: Cortez, 2011.

ARRUDA, João. Canudos: messianismo e conflito social. Fortaleza: UFC, 2006.

BARTELT, Dawid Danilo. Sertão, república e nação. São Paulo: USP, 2009.

CALASANS, José. Aparecimento e prisão de um messias. Revista da Academia de Letras da Bahia, Salvador, n.35, set, 1988.

CALASANS, José. O Estado-Maior de Antônio Conselheiro: quase biografias de jagunços. São Paulo: GRD, Edição revista e ampliada, 2000.

CUNHA, Euclides da. Os sertões. São Paulo: Martin Claret, 2016.

DELlA CAVA, Ralph. Milagre em Joaseiro. Trad. De Maria Yedda Linhares. São Paulo: Companhia das Letras, $3^{\text {a }}$.ed. 2014.

FACÓ, Rui. Cangaceiros e Fanáticos. Rio de Janeiro: Editora Civilização Brasileira, $5^{\text {a }}$. ed. 1978.

HOBSBAWM, Eric. Bandidos. São Paulo: Paz e terra, 2017.

JASMIN, Élise. Lampião: senhor do sertão. São Paulo: USP, 2016.

MELlO, Frederico Pernambucano de. A guerra total de Canudos. São Paulo: Escrituras, 2014.

MELLO, Frederico Pernambucano de. Estrelas de couro: A estética do cangaço. São Paulo: Escrituras, 2015. 
MELLO, Frederico Pernambucano de. Guerreiros do sol: violência e banditismo no Nordeste do Brasil. São Paulo: A Girafa Editora, 2004.

MENEZES, Celso Vianna Bezerra. Rituais de devoção: os herdeiros do milenarismo do Contestado. In: PEREIRA, João Baptista Borges; QUEIROZ, Renato da Silva (orgs). Messianismo e milenarismo no Brasil. São Paulo: USP, 2015. p. 129-151.

NEGREIROS, Adriana. Maria Bonita: Sexo, violência e mulheres no cangaço. Fortaleza: Objetiva, 2018.

POMPA, Cristina. Memória do Fim do mundo. In: PEREIRA, João Baptista Borges; QUEIROZ, Renato da Silva (orgs). Messianismo e milenarismo no Brasil. São Paulo: USP, 2015. p. 99-127.

VASCONCELLO, Pedro Lima. Arqueologia de um monumento: os apontamentos de Antônio Conselheiro. São Paulo: É, 2017.

RICARTE LANZ, Helza. Elendsviertel. In: BURGHARDT, Daniel; ZIRFAS, Jörg. Pädagogische Heterotopien. Weinheim: Beltz Juventa, 2018. p. 71-81.

SAMPAIO, Consuelo Novais. Canudos: a construção do medo. In: Canudos: Cartas para o Barão. São Paulo: USP, 2001. p. 31-85.

SANTOS, Luís Sérgio. Rui Facó (uma biografa): o homem e sua missão. Fortaleza: Omni, 2014.

STUNTENBECK, Harald. Canudos. Eine sozial-religiöse Volksbewegung in Brasilien und ihre pastorale Wirkungsgeschichte. Münster: LIT, 2016. 